\title{
POSITIVE AND NEGATIVE EFFECTS OF THE APPLICATION OF THE CITIZENSHIP LAW IN THE REPUBLIC OF MACEDONIA
}

\author{
Assoc. Prof. Jadranka Denkova \\ University of "Goce Delchev", Faculty of Law \\ 2000 Shtip, Macedonia, jadranka.denkova@ugd.edu.mk \\ Elena Gjorgjieva, Master \\ Assistant in Governing Service, Police Station Vinica, Macedonia \\ elenagjorgjieva@yahoo.com
}

\begin{abstract}
The main focus of this paper is to identify and analyze the positive and negative effects that apply in practice from the provisions of the Citizenship Law in the Republic of Macedonia. The main purpose of this article is show various experiences of people who have went through the process of acquiring citizenship ${ }^{1}$ of The Republic Macedonia. Some practical examples show that the process of acquiring a Macedonian Citizenship can be bumpy and painful and as a result of that many people give up in the early beginning of the process, while others do not even want to apply.

On the other hand, based on the explanations of representatives of the institutions, the procedure sounds quite simple and logical. As a result of these two contradictory comments on the basis of the procedures and legal provisions that regulate this issue, this paper aims to differentiate between the existing dilemmas in high academic circles regarding the positive and negative consequences of the application of the acquisition of citizenship of The Republic Macedonia. The conclusion will be based on practical examples and the results of the conducted panel survey.
\end{abstract}

Keywords: Citizenship; Legal provisions; Positive and negative consequences; Citizenship Law of The Republic of Macedonia.

\section{Introduction}

Based on different marks, many concepts have been used to define the genesis of the state ${ }^{2}$. Even though some of them assess the elements in a different

${ }^{1}$ Acquisition of citizenship refers to the mechanism by which certain individuals obtain their right to become legal citizens of a specific state.

${ }^{2}$ The genesis of the state refers to the state origins in legal form. way, the conclusions are the same. The state cannot exist without people. In fact, state is a community of people that is defined as one nation under the same government. This has emerged as one of the basic features for its existence along with the territory and borders. Its existence cannot even remotely be imagined without the existence of the population.

Therefore, the main idea in this paper is to analyze the relationship between a person and the state. This relationship is called citizenship and is regulated by the Citizenship Law. The legal theory defines citizenship as a separate or a special legal relationship that exists between the individual and the state. Citizenship as a legal category, in each state is regulated by a special law and autonomously ${ }^{3}$. The right of citizenship means the right of an individual to be a citizen of a particular state or his right to establish a legal relationship with the state in which lives and operates.

To understand the main features and institutions that regulate the citizenship, as well as to define properly the rights and obligations under this regulation, this paper will analyze the key principles and procedures for acquisition of citizenship. The focus will be directed

\footnotetext{
${ }^{3}$ Autonomously is stated for the right of self-government.
} 
towards the provisions of the citizenship ${ }^{4}$ of the Republic of Macedonia, which regulates the conditions for the acquisition and termination of citizenship and the procedure for its award. One should bear in mind that citizenship is a legal link between the citizen and the state and does not indicate the ethnic origin of the citizen.

\section{What is Citizenship?}

In order to define the citizenship, first one should be able to differentiate its meaning from nationality. In many cases confusion arises when answering the question of nationality. These two terms are quite related, but that does not mean that people should not distinguish between them. Nationality states for the affiliation of an individual to a particular nation. Although each nation has its own people, it does not mean that every one of them has to have the same nationality. Nationality is an ethnic term, while the citizenship refers to the meaning of the legal relation between the individual and the state. Or put it differently, each state has its own citizens, but not all of them have to be the same nationality.

In the legal theory, citizenship implies a special legal relationship or particular legal bond between the individual and the state. Citizenship is not territorial but personal relationship between the citizen and the state. Citizenship is not limited within the territory of a country. When a person travels to a foreign country, the citizenship retains which means the rights and obligations of the citizen and the state do not stop when crossing the borders.

Therefore, the scope of the establishment and termination of citizenship are regulated by the legislation of each state autonomously. In Macedonia,

${ }^{4}$ Provisions of the citizenship law are the legal clauses or conditions contained within the law that regulate different measures and mechanisms within the law. the citizenship is regulated by the Citizenship Law of the country. This law regulates the manner and conditions for acquisition and termination of citizenship of the Republic of Macedonia, the determination and verification of citizenship, the state authority responsible for related issues, the proofs of citizenship and keeping records and data set of Macedonian citizens.

In the Constitution of Macedonia, citizenship is defined as a separate legal relationship (link) between the individual and the state. Such an attitude guarantees the citizens' right to vote as well as the enjoyment of legal freedoms. It is a legal link because it is regulated by a unilateral act - the Constitution and the Law.

\section{The Meaning of Citizenship}

What does it mean if one lives in a certain state's territory? Can a person acquire certain rights by the right of citizenship? Are people entrusted to protection by being citizens of a certain state? Do they have the right to work? Can they participate in the government? Do they have the freedom and right to establish their family?

The answers of all these questions reflect the real meaning of obtaining a citizenship. It is very important to highlight that each person is entitled to certain rights and obligations with the act of birth. These rights are equal for everyone. But in order to obtain rights and obligations in the legal system, certain conditions are required as: legal, working and delict ${ }^{5}$ capacity. Furthermore, a person has to meet the following features as well: name, residence, and citizenship.

As it is stated, one of the main attributes that should be possessed by a person in order to obtain certain rights as

\footnotetext{
${ }^{5}$ Delict capacity of a person is defined as
} the circumstances under which one can claim compensation from another for harm that has been suffered. 
an individual is the citizenship. The citizenship defines and differentiates the rights and obligations of the citizens of one country and the foreigners. The legal significance is also found in the It is an opportunity for individuals to enjoy all civil, political, economic and social rights of the home country. These features do not imply that a citizen has only rights in a particular country, but also its duty to fulfill certain obligations towards the state.

On the other hand, the state also has rights and obligations towards its citizens. There is no equality or equivalence between the rights and obligations between these two stakeholders. The state is found to be a very powerful institution in comparison to the individual, and therefore determines the requirements from individuals itself as well as the provided favorable treatment in return.

Citizenship as a right not only confirms the identity of the individual, but also gives the individual the right to state protection and numerous other civil and political rights. These include the mutual relations of the basic constituent agents of the political regime that is the individual and the state, which relations are laid on the basis of unbreakable bonds and at the same time refer to the main principles (which will be discussed later), so that each of these two subjects act in politics as two distinct and interrelated and conditioned parts. Thus formulated the right to citizenship represents the basis for the existence of a democratic political regime in one given country.

The significance of nationality also derives from the fact that it provides equality of the state and the citizen in their mutual legal relationship and it represents a form of guarantee of their adequate independence. The citizenship provides the individual with a solid fund of assets to make impact on the state, such as participation in elections, criticism, selfmanagement and other.

Citizenship gives people the right to participate in the process of decisionmaking for the future of their country.

\section{Types of Citizenship}

Based on the different way of acquiring and termination, there are several different forms or types of citizenship:

- Stateless people (individuals without citizenship)

- Dual citizenship (people with two citizenships)

- Multiple citizenship (persons who have more than two citizenships)

On the territory of a country may enter people who do not have the same country citizenship. These people are called foreigners or strangers. As foreigners, they also have rights and obligations towards the state, but to a limited extent in relation to its actual citizens.

\section{Theoretical, scientific and methodological approach to the research problem}

At the beginning of this paper, the theoretical framework of the problem referring to the positive and negative consequences of the Law on Citizenship of the Republic of Macedonia was defined. But, in order to achieve results upon which a relevant discussion can take place, the scientific approach to the research problem will be determined.

This paper tends to establish and develop a comprehensive approach of the pros and cons of the Citizenship Law in Macedonia, based on theoretical, scientific and methodological approach to the problem. The findings are planned to be beneficial for the target groups such as: 
immigrants ${ }^{6}$, existing and potential citizens of Macedonia.

Many scholars and academics did a research related to this issue indicating citizens' demands for simplification of procedures and review of conditions in order to eliminate opportunities for unsubstantiated revocation or non-issuing a citizenship.

It is advised by that that the national policy and strategy de facto must follow the new developing processes and needs of the modern way of living. On the other hand, the question which is treated, is no longer in itself an institutional issue that should be resolved, but it requires sustained and adequate reforms and amendments of the Law that will efficiently apply. It also requires a simple procedure, simultaneously building free of abuse society enabled to respond to the national requirements imposed by the global and European societies.

\section{Legal framework for citizenship acquisition of the Republic of Macedonia}

The legal regulations governing this matter in Macedonia, involve the acquisition of citizenship on the basis of: naturalization, marriage, immigrant or child of an immigrant, refugees and stateless persons.

For a person to be eligible to acquire citizenship, one of the following principles has to be preserved:

1) principle of origin (if the person has a parent / parents who is / are citizen / citizens of the Republic of Macedonia)

2) birth within the territory of the Republic of Macedonia,

3) by means of naturalization ${ }^{7}$ and

\footnotetext{
${ }^{6}$ An immigrant is a person who leaves one country to settle permanently in another.

${ }^{7}$ NATURALIZATION is the legal act or process by which a non-citizen in a country may acquire citizenship or nationality of that country.
}

4) international agreements.

Individuals who are eligible for citizenship of the Republic of Macedonia can start the procedure for obtaining their legal right in the nearest diplomatic or consular mission in the country of residence or in the offices of the state authorities in Macedonia. The procedure starts by filing a request for acquisition of citizenship and submitting the additional supporting documentation according to the basis for citizenship acquisition.

The state authorities in Macedonia claim that the procedure for citizenship acquisition and termination is quite simple. Each step of the procedure including the necessary documents is explained in a clear and comprehensive way on the website of the Ministry of Interior and at the competent authorities. According to them, the necessary documentation is not complex at all, but is consisted by several documents necessary to ascertain the basis for acquisition of citizenship and identification of the applicant.

In order to determine whether the claims of representatives of relevant institutions regarding the complexity of the procedure for obtaining citizenship are appropriate to the actual situation, a panel survey was conducted. The survey was created in a way to access information about the procedure, the required documentation and some real examples that will support the basic conclusions. The main objective of the survey is to have a clear picture of the problem after processing the data obtained from the survey by questionnaire.

The questionnaire was prepared in 10 copies, each of them delivered to the offices of the authorities of the Department for identification, acquisition and termination of citizenship of the Interior in different cities of the Eastern region of the country, including the capital - Skopje. The questionnaire was consisted of 15 clear questions about the positive and 
negative effects of application of the Citizenship Law of the Republic of Macedonia. After processing the answers and other relevant information, the positive and negative impact of this regulation can be determined.

According to the results of the conducted survey, in the first half of 2015, 489 individuals have gained status of citizenship of the Republic of Macedonia. Almost $25 \%$ or 124 citizenships were accounted for citizens of Albania, 73 for citizens of Kosovo, 55 for citizens of Serbia, 28 for Turkey citizens and 18 citizens of Austria.

The total number of citizenships granted in the previous year was 1072. Regarding to the principles of citizenship acquisition, 670 foreign nationals have acquired Macedonian citizenship based on marriage in 2014. Of the total number, 206 of the issued citizenships were based on origin, while only 21 obtained Macedonian citizenship on the basis of meeting the requirement for continuous stay of 8 years. As the officials from the Interior Ministry have stated, expats who have acquired Macedonian citizenship in this period, had a prior registered legal residence in the country.

The number of citizenship requirement, and thus the number of issued citizenships is followed by a negative trend in the last few years:

\begin{tabular}{|l|l|}
\hline \multicolumn{2}{|c|}{ Number of Foreign nationals that have gained status of Macedonian citizens: } \\
\hline Year: & Number of Citizenships: \\
\hline 2011 & 1186 \\
\hline 2012 & 1174 \\
\hline 2013 & 1270 \\
\hline 2014 & 1072 \\
\hline Total: & 4712 \\
\hline
\end{tabular}

Figure 1: Total number of foreign nationals who have acquired Macedonian citizenship in the period from 2011 to 2014;

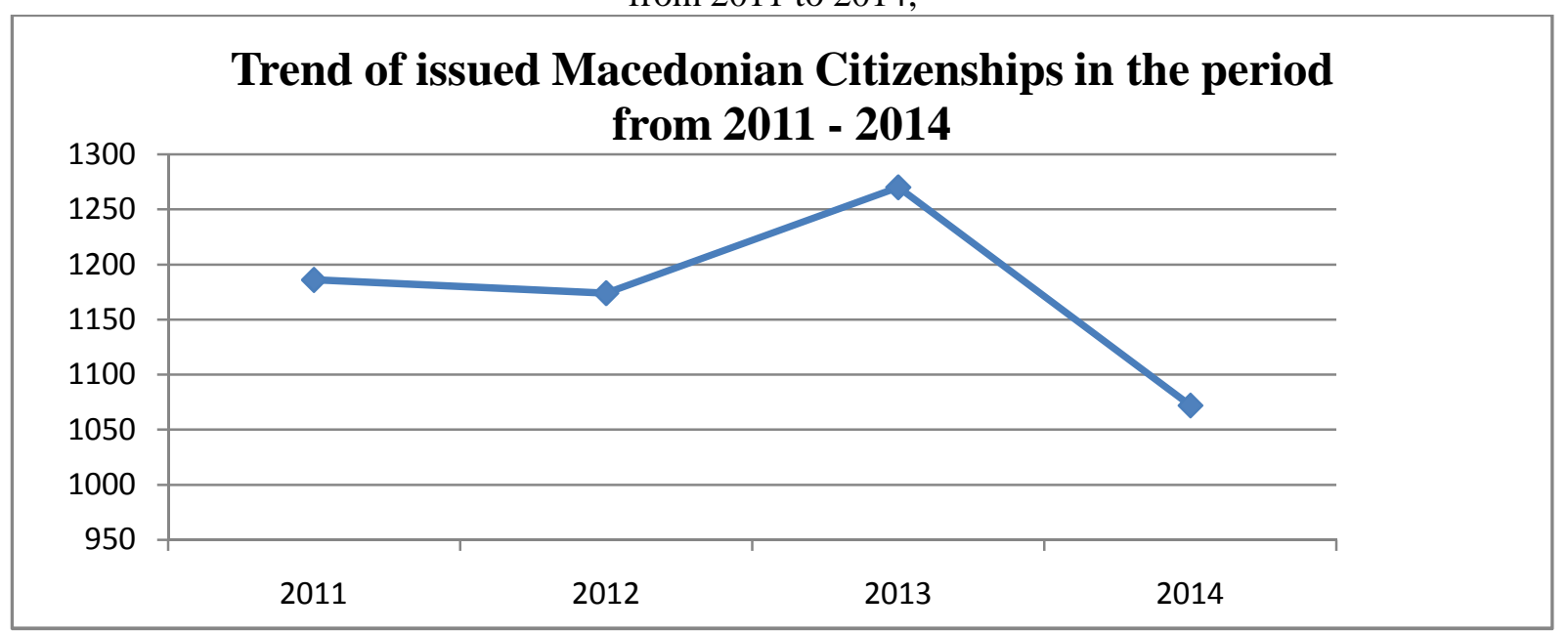

Figure 2: Graphical trend of the total number of foreign nationals who have acquired Macedonian citizenship in the period from 2011 to 2014; 
According to the relevant data by the Ministry of Interior, there has been a decline in the number of foreign nationals who wish to acquire the citizenship of Macedonia in recent years. The total number of issued citizenships in the period of 2011-2014 in the figure is 4712, which in fact represents less than $5 \%$ of the total citizenships issued to foreigners in the period from 1992 to 2014.

After 2002, one year after the conflict, when the register enrolled 8040 new citizens of Macedonia, every next year is followed by diminishing trend.

If the procedure is explained to be simple by the state officials from the Interior, one would wonder what are the main reasons behind the diminishing trend? The findings from the survey indicate that good part of the requests by individuals for acquisition; establishment and termination of citizenship are being rejected. According to the respondents, one of the most common reasons is the failure to meet the conditions.

On the other hand, state officials say that incomplete documentation is not a ground for refusing the request. On the contrary, if someone does not meet the requirement for completed documentation, state officials themselves will emphasize it and direct applicants to the appropriate institutions for obtaining the specified document.

Within the remaining issues was inserted the question of knowing the procedure for identification, acquisition and termination of citizenship, as well as having clear instructions and guidelines by the officials from the register of the Interior. The survey indicates at excellent knowledge of the entire procedure, with certain possibilities of consultation with colleagues or manual work in situations of complex character. Although the majority believes that the procedure is simple, some findings indicate that some parts of the procedures can be complex and therefore have negative impact on the interest and need for acquisition of citizenship of the Macedonian nationals living abroad. The different findings by obtaining different data sets indicate towards the presence of subjectivity by the state officials in answering the questionnaire of the survey.

Furthermore, some of the previous statements are not correlated with the responses that indicate the need of undergo of certain amendments and provisions of the Citizenship Law in order to meet the modern migration approach.

More than half of respondents $(60 \%)$ believe that the establishment of clear laws and procedures in the Citizenship Law of the Republic of Macedonia will be followed by fast and efficient administrative procedures for obtaining citizenship.

\section{Conclusion}

The represented findings from the panel survey conducted by anonymous questionnaire lead to an overall conclusion that the general hypothesis, which refers to implementation of clear laws and procedures in the Citizenship Law of the Republic of Macedonia will result in fast and efficient administrative procedures for obtaining citizenship.

The main findings indicate to the following:

- Complexity in the administrative procedure for acquisition of citizenship will have a negative impact of the interest and need for citizenship acquisition of Macedonian nationals living abroad.

- Legal provisions of the Law for acquiring Macedonian citizenship should also include sort of protection remedies for nationals of the Republic of Macedonia.

- Efficient resolution of pending citizenship will affect the country's image abroad.

- State officials entitled for citizenship in the Interior should be provided with clear instructions and guidance on the application of laws in order to enable operational efficiencies. 
- The officials should be provided with working conditions envisaged by the law and standards.

It is especially important to mention that currently there are certain flaws in the legal framework that regulates the issue of citizenship. This form of regulation has not yet developed into a high-effective form that will satisfy all listed conditions.

However, the Republic of Macedonia has committed to effectively manage overall processes, procedures, requirements, and conditions when it comes to this issue, taking into account national, social, economic and cultural development. Macedonia should continue to observe and follow the positive examples of EU legislation and international practice. The state must enable the integration of its expatriates and to provide a simple and effective way for them to acquire Macedonian citizenship. The state must provide protection for its nationals outside the country and ensure their rights of citizenship. In achieving these goals, the state commitments should be complemented by the principle of protection of citizens living within the territory of Macedonia and the protection its national interests.

\section{References:}

1. Vlado G., Radmila K., \& Victoria M., (2010) "Fundamentals of law", Skopje.

2. Goss P.R., (1996) "A Distinct Public Administration Ethics?“, Journal of Public Administration Research and Theory, Accessed on February 27, 2016: http://jpart.oxfordjournals.org/content/6/4/5 73. abstract.

3. Government of the Republic of Macedonia, (2008) "Resolution on the migration policy of the Republic of Macedonia 2009-2014", Skopje.

4. Official Gazette., (2011) Administrative Law of the Republic of Macedonia, Second revised edition, Skopje, Macedonia.

5. Official Gazette., (2011) Citizenship Law of the Republic of Macedonia, Revised Edition No.158/11, Skopje, Macedonia. 